\title{
The Isolated ER-Golgi Intermediate Compartment Exhibits Properties That Are Different from ER and cis-Golgi
}

\author{
Anja Schweizer, Karl Matter, Catherine M. Ketcham, ${ }^{*}$ and Hans-Peter Hauri \\ Department of Pharmacology, Biocenter of the University of Basel, CH-4056 Basel/Switzerland; * Division of Hematology-Oncology, \\ Washington University, School of Medicine, St. Louis, Missouri 63110
}

\begin{abstract}
A procedure has been established in Vero cells for the isolation of an intermediate compartment involved in protein transport from the ER to the Golgi apparatus. The two-step subcellular fractionation procedure consists of Percoll followed by Metrizamide gradient centrifugation. Using the previously characterized p53 as a marker protein, the average enrichment factor of the intermediate compartment was 41 . The purified fraction displayed a unique polypeptide pattern. It was largely separated from the rough ER proteins ribophorin I, ribophorin II, BIP, and protein disulfide isomerase, as well as from the putative
\end{abstract}

cis-Golgi marker $N$-acetylglucosamine-1-phosphodiester- $\alpha-N$-acetylglucosaminidase, the second of the two enzymes generating the lysosomal targeting signal mannose-6-phosphate. The first enzyme, $N$-acetylglucosaminylphosphotransferase, for which previous biochemical evidence had suggested both a pre- and a cis-Golgi localization in other cell types, cofractionated with the cis-Golgi rather than the intermediate compartment in Vero cells. The results suggest that the intermediate compartment defined by p53 has unique properties and does not exhibit typical features of rough ER and cis-Golgi.
$\mathrm{N}$ EWLY synthesized exocytic proteins leave the ER at the transitional elements of the rough ER (Palade, 1975 ) and migrate to the Golgi apparatus through a recently identified intermediate compartment (Saraste and Kuismanen, 1984; Schweizer et al., 1990). This transport intermediate is defined by $\mathrm{p} 53$, a $53-\mathrm{kD}$ nonglycosylated homooligomeric transmembrane protein (Schweizer et al., 1988). In Vero cells cultured at $37^{\circ} \mathrm{C}$, p53 labels a tubulovesicular membrane system in the vicinity of the cis-side of the Golgi apparatus. Newly synthesized $G$ protein was shown to accumulate in the $p 53$ compartment at $15^{\circ} \mathrm{C}$ demonstrating that p53 identifies an ER-to-Golgi intermediate of the exocytic protein transport pathway of Vero cells (Schweizer et al., 1990).

Besides mediating exocytic protein transport the functions of the ER-Golgi intermediate compartment are unknown. A number of cellular mechanisms have been postulated to occur at a post-ER pre-Golgi site such as salvage of ER components (Warren, 1987; Wieland et al., 1987; Pelham, 1988, 1989; Lippincott-Schwartz et al., 1990; Vaux et al., 1990), the first step of $O$-glycosylation (Tooze et al., 1988), fatty acylation of proteins (Rizzolo et al., 1985; Rizzolo and Kornfeld, 1988; Bonatti et al., 1989) or the first enzymatic step in the generation of the mannose-6-phosphate signal for lysosomal protein targeting (Pelham, 1988; Kornfeld and Mellman, 1989) but precise localization of these functions has been elusive.

One approach to elucidate the characteristics and func-

K. Matter's present address is Department of Cell Biology, Yale University, School of Medicine, New Haven, CT 06510. tions of the p53 compartment is its isolation. Using p53 as a marker protein we have now established a subcellular fractionation procedure combining self-forming Percoll and Metrizamide density gradient centrifugation for the isolation of the ER-Golgi intermediate compartment from Vero cells. The isolated intermediate compartment is largely separable from rough ER and cis-Golgi elements suggesting that it has unique properties.

\section{Materials and Methods}

\section{Materials}

Reagents and supplies were obtained from the following sources. DMEM ( $4.5 \mathrm{~g} /$ liter of glucose), penicillin, streptomycin, fungizone, nonessential amino acids were from Gibco Laboratories (Paisley, Scotland), FCS from Biological Industries (Israel), cell culture dishes from Falcon Labware (Becton Dickinson \& Co., Cockeysville, MD), SDS-PAGE reagents from Serva Biochemicals (Heidelberg, FRG), Percoll from Pharmacia Fine Chemicals (Uppsala, Sweden), Metrizamide from Nycomed (Oslo, Norway), trypsin inhibitor and $p$-nitrophenyl- $N$-acetyl $\beta-\mathrm{B}$-glucosaminide from Sigma Chemical Co. (St. Louis, MO), $\left[{ }^{14} \mathrm{C}\right]$ uridine-5'-diphospho-D-galactose from New England Nuclear (Boston MA), 4-nitrophenylphosphate disodium salt from Merck (Darmstadt, Germany), nitrocellulose from Schleicher \& Schuell Inc. (Keene, NH), powdered milk (Sanolait, Basel) from Coop (Switzerland), fish gelatine from Inotech A. G. (Wohlen, Switzerland), rabbit anti-mouse Ig G1 antibody from Nordic Immunology (Tilburg, The Netherlands), and glutaraldehyde from Fluka Chemical (Buchs, Switzerland). Protein A was iodinated with $\mathrm{Na}^{125} \mathrm{I}$ by the chloramine $\mathrm{T}$ procedure.

\section{Cell Culture}

Vero cells (African green monkey kidney cells) were grown in Optilux petri 
dishes (Becton Dickinson Co., Lincoln Park, NJ) in DMEM supplemented with $5 \% \mathrm{FCS}, 100 \mathrm{U} / \mathrm{ml}$ penicillin, $100 \mu \mathrm{g} / \mathrm{ml}$ streptomycin, $1 \mu \mathrm{g} / \mathrm{ml}$ fungizone under standard tissue culture conditions.

\section{Antibodies}

Mouse mAb Gl/93 against the $53-\mathrm{kD}$ protein has previously been characterized (Schweizer et al., 1988). A polyclonal antibody against the denatured $53-\mathrm{kD}$ protein was produced as follows. The $53-\mathrm{kD}$ protein was immunoprecipitated from Caco-2 membranes using $\mathrm{mAb}$ G1/93 and the immunoprecipitate was subjected to SDS-PAGE. The p53 band was cut out of the gel, homogenized in PBS with a glass-Teflon potter, and mixed with complete Freund's adjuvant. The resulting emulsion was subcutaneously injected into a New Zealand White rabbit. Booster injections with antigen in incomplete Freund's adjuvant were given 1,5 , and 12 mo later by the same route. 1 wk after the third booster the rabbit was killed and the serum was harvested. Mouse mAbs directed against ribophorin I and II (Hortsch et al., 1986) were a kind gift of Dr. D. Meyer (University of California, Los Angeles). Rabbit polyclonal antibodies to protein disulfide isomerase and BIP (Vaux et al., 1990) were generously provided by Dr. S. Fuller (European Molecular Biology Laboratory); they were raised against peptides containing the carboxy-terminal tail of either protein disulfide isomerase (KDDDKAVKDEL) or BIP (KEEDTSEKDEL).

\section{Isolation of the p53 Compartment (Fig. 1)}

All the steps of the isolation procedure were carried out at $4^{\circ} \mathrm{C}$ unless indicated otherwise. Vero cells (12 100-mm petri dishes per preparation) were washed once with $0.9 \%$ (wt/vol) $\mathrm{NaCl}$ and once with $250 \mathrm{mM}$ sucrose, 10 $\mathrm{mM}$ triethanolamine-acetic acid, $\mathrm{pH} 7.4$ (buffer A). The cells were then scraped from the dishes, suspended in $2 \mathrm{ml}$ per three $100-\mathrm{mm}$ dishes 250 $\mathrm{mM}$ sucrose, $1 \mathrm{mM} \mathrm{Na}{ }_{2} \mathrm{EDTA}, 10 \mathrm{mM}$ triethanolamine-acetic acid, $\mathrm{pH}$ 7.4 (buffer B), and centrifuged for $5 \mathrm{~min}$ at $560 \mathrm{gav}$. The cell pellet was gently resuspended in $2 \mathrm{ml}$ of buffer $B$ and centrifuged as above. The cells were then resuspended in $3 \mathrm{ml}$ of buffer $B$ and homogenized by passing them 10 times through a ball-bearing homogenizer (Balch and Rothman, 1985) with a clearance of $20 \mu \mathrm{m}$. The resulting homogenates were pooled and centrifuged for $10 \mathrm{~min}$ at $2,000 \mathrm{rpm}(370 \mathrm{gav}$ ) in an SS34 rotor (Sorvall Instruments Division, Norwalk, CT). The supernatant was brought to exactly 30 $\mathrm{ml}$ with buffer B and $3.96 \mathrm{ml}$ stock isoosmotic Percoll (density of Percoll $=1.129$, initial density $=1.046$ ) were added. The Percoll gradient was centrifuged for $41 \mathrm{~min}$ at $20,000 \mathrm{rpm}(36,900 \mathrm{gav}$ ) in a RC2B centrifuge (Sorvall Instruments Division) using the same rotor as above. For the determination of marker enzyme activities and p53 distribution of this Percoll gradient, 23 fractions were collected beginning at the bottom. For the isolation of the p53 compartment $7.5 \mathrm{ml}$ from the bottom of the gradient were discarded. The next $13.5 \mathrm{ml}$ were pooled and processed for two identical gradients as follows: $6.75 \mathrm{~g}$ of this fraction were adjusted to $30 \%(\mathrm{wt} / \mathrm{wt})$ Metrizamide and overlaid with $3.5 \mathrm{ml}$ of each $27 \%$ and $18.5 \%(\mathrm{wt} / \mathrm{wt})$ Metrizamide in $1 \mathrm{mM} \mathrm{Na} 2 \mathrm{EDTA}, 10 \mathrm{mM}$ triethanolamine-acetic acid, $\mathrm{pH}$ 6.5 (buffer C). Finally the tube was filled with buffer B. The gradient was run to equilibrium $(18-20 \mathrm{~h})$ at $25,000 \mathrm{rpm}(85,800 \mathrm{gav})$ in a TST $28.17 \mathrm{ro}-$ tor (Kontron Electronic GmbH, Zurich, Switzerland) at $8^{\circ} \mathrm{C}$. The $27 \%$ : $18.5 \%$ interphase was harvested, diluted with PBS and centrifuged at $39,000 \mathrm{rpm}(105,000 \mathrm{gav})$ for $1 \mathrm{~h}$ at $4^{\circ} \mathrm{C}$ in a TFT 65.13 rotor (Kontron Electronic $\mathrm{GmbH})$. The pellet was resuspended in PBS. This fraction was designated $\mathrm{F} 3$.

\section{Enzyme Assays}

The following marker enzymes were used: alkaline phosphatase (measured according to Stieger et al., 1986) for the plasma membrane, glucosaminidase (measured according to Scalera et al., 1980) for lysosomes, galactosyltransferase (measured according to Venable and Coggeshall, 1965; Stieger et al., 1988) for trans-Golgi and KCN-resistant NADH oxidoreductase (measured according to Sottocasa et al., 1967) for the ER. Protein was determined with the Bio-Rad protein assay kit using protein standard I (BioRad Laboratories Munchen, Germany).

UDP- $N$-acetylglucosamine:lysosomal enzyme $N$-acetylglucosamine-1phosphotransferase ( $N$-acetylglucosaminylphosphotransferase, phosphotransferase) was measured as follows: $\left[\beta^{32} \mathrm{P}\right]$ uridine diphospho- $N$-acetylglucosamine ([ $\left.\beta \beta^{32} \mathrm{P}\right]$ UDPGicNAc) ${ }^{1}$ was synthesized according to the method of Lang and Kornfeld (1984). N-acetylglucosaminylphosphotransferase 1. Abbreviations used in this paper: BIP, immunoglobulin-binding protein; GlcNac, $N$-acetylglucosamine. assays were carried out as previously described (Reitman et al., 1984). [ $\beta^{-32}$ P]UDP GlcNAc was used at $50-100 \mu \mathrm{M}$ with a specific activity of $133-400 \mathrm{cpm} / \mathrm{pmol}$ and methyl- $\alpha$-D-mannopyranoside at $100 \mathrm{mM}$ was used as acceptor. One unit of activity is defined as 1 pmol GlcNAc-phosphate transferred per hour.

The assay for $N$-acetylglucosamine-1-phosphodiester- $\alpha-N$-acetyl-glucosaminidase (uncovering enzyme) was as follows: The substrate $\left[6-{ }^{3} \mathrm{H}\right] \mathrm{N}$ acetylglucosamine 1'-( $\alpha$-D-methylmannopyranose 6-monophosphate), was prepared to a specific activity of $1,500 \mathrm{cpm} / \mathrm{pmol}$ essentially as described previously (Tong et al., 1989). Enzyme samples and $\left[6-{ }^{3} \mathrm{H}\right] \mathrm{N}$-acetylglucosamine $1^{\prime}-(\alpha-D$-methylmannopyranose 6-monophosphate) (at $0.12-0.24$ $\mathrm{mM}$ ) were incubated in $50 \mathrm{mM}$ Tris-maleate, $\mathrm{pH} 6.8,0.5 \%$ (wt/vol) Triton $\mathrm{X}-100$ and $5 \mathrm{mg} / \mathrm{ml} \mathrm{BSA}$ at $37^{\circ} \mathrm{C}$ for $2 \mathrm{~h}$. The $25-50-\mu \mathrm{l}$ reaction was stopped by the addition of $1 \mathrm{ml} 5 \mathrm{mM}$ EDTA, pH 7.8. Samples were then loaded onto $0.5 \times 1.5 \mathrm{~cm}$ quaternary aminoethyl Sephadex columns that had been equilibrated in $2 \mathrm{mM}$ Tris base. Liberated $\left[6-{ }^{3} \mathrm{H}\right] \mathrm{GlcNAc}$ was collected by washing with $2 \mathrm{mM}$ Tris base and detected by liquid scintillation counting. One unit of activity is defined as 1 pmol GlcNAc released per hour.

\section{Quantification of 53 in Subcellular Fractions}

The quantification of p53 was based on a dot-blot procedure (Hawkes et al., 1982) and performed as follows: from the cell fractions to be assayed 4, 2,1 , and $1 \mu \mathrm{l}$ of twofold serial dilutions in PBS were dotted onto a nitrocellulose filter. After air drying overnight and blocking with $1 \%$ powdered milk in PBS, the dots were sequentially incubated for $2 \mathrm{~h}$ each with an IgG fraction of mAb G1/93 (5 $\mu \mathrm{g}$ per dot in blocking solution), a rabbit anti-mouse Ig $\mathrm{Gl}$ antibody (1:500 in blocking solution and ${ }^{125} \mathrm{I}$-protein A $(500,000$ cpm per dot). Labeled dots were visualized by autoradiography using Fuji RX films. Quantification of autoradiograms was carried out by means of a Molecular Dynamics 300A computing densitometer (Molecular Dynamics, Sunnyvale, CA). The data of the radiometric assay were analyzed by computer as described by Gorr et al. (1988).

\section{SDS-PAGE and Immunoblotting}

Proteins were separated on $8.5 \%$ SDS-polyacrylamide slab gels using the Laemmli system (Laemmli, 1970) and stained with Coomassie brilliant blue or transferred to nitrocellulose sheets according to the method of Towbin et al. (1979). For the immunoreaction the nitrocellulose sheet was incubated with the antibody of choice followed by ${ }^{125}$ I-protein $A$ in the presence of PBS-3\% fish gelatine- $-0.05 \% \mathrm{NP}-40$ for the anti $\mathrm{p} 53$ polycional antibody or in the presence of PBS-1\% powdered milk for all other antibodies (Hauri and Bucher, 1986).

\section{Electron Microscopy}

A sample of the $\mathrm{F} 3$ fraction was prefixed at room temperature by adding
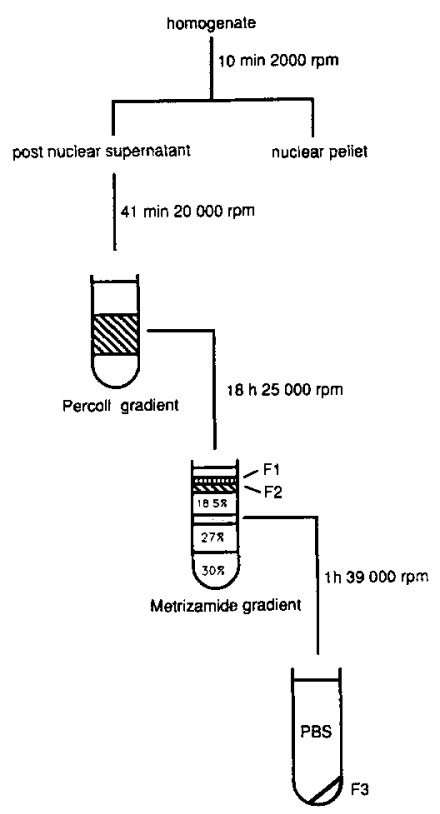

Figure 1. Flow diagram for the isolation of the p53 compartment fraction (F3). 

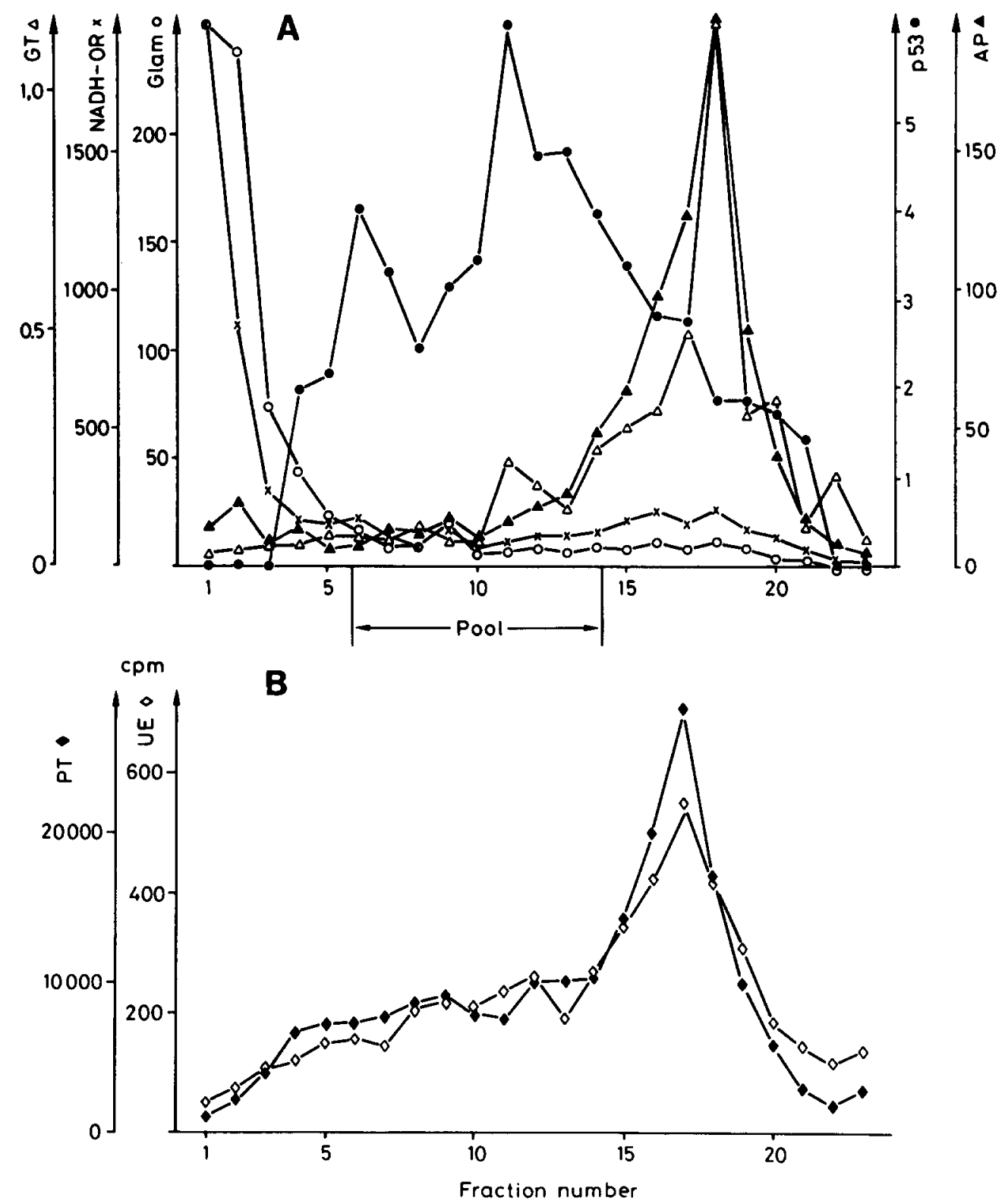

Figure 2. Distribution of p53 and marker enzymes on Percoll gradients. Postnuclear supernatants from Vero cells were fractionated on $10.5 \%$ Percoll gradients. The gradient was divided into 23 fractions of $1.5 \mathrm{ml}$ beginning at the bottom. ( $A$ ) Enzymatic activities of alkaline phosphatase $(A P)$, glucosaminidase (Glam), galactosyltransferase (GT), and KCN-resistant NADH oxidoreductase (NADH-OR) are given in milliunits/milliliter. P53 was detected by immunoblotting; values are given in arbitrary units/milliliter. (B) Enzymatic activities of $N$-acetylglucosaminylphosphotransferase $(P T)$ and uncovering enzyme $(U E)$ are given in counts per minute.

a stock solution of glutaraldehyde ( $8 \%$ ) to a final concentration of $1 \%$. After 15 min the samples were stored at $4^{\circ} \mathrm{C}$ until further processing. The fractions were then suspended for $3 \mathrm{~h}$ at $4^{\circ} \mathrm{C}$ in PBS containing $1 \%$ glutaraldehyde. The fixed material was centrifuged in an airfuge (Beckman Instruments, Fullerton, CA) for $15 \mathrm{~min}$ at $150,000 \mathrm{gav}$. Pooled pellets were postfixed for $30 \mathrm{~min}$ at $4^{\circ} \mathrm{C}$ in a $2 \%$ solution of osmium tetroxide in $0.1 \mathrm{M}$ cacodylate buffer (pH 7.2). The postfixed material was dehydrated and embedded in Epon/araldite according to standard procedures. Thin sections were stained with uranyl acetate and lead citrate and examined in a Philips EM 400 transmission electron microscope.

\section{Results}

\section{Two-Step Isolation Procedure of the p53 Intermediate Compartment}

Vero cells were used as a starting material for the purification of the p53 compartment. This cell line was chosen based on our previous study (Schweizer et al., 1990) which established the p53 compartment as an intermediate of the ER-to-Golgi protein transport pathway. Since mAb G1/93 recognizes an epitope on the extracytoplasmic side of p53 (Schweizer et al., 1988) it was not possible to isolate the p53 compartment by affinity methods. Therefore the isolation was based on self-forming Percoll and Metrizamide equilibrium density gradients using p53 as a marker protein (Fig. 1).

The first step of the isolation procedure was derived from . pilot studies showing that the p53 compartment displayed an intermediate density on self-forming Percoll gradients when compared with ER and Golgi markers. The Percoll gradient of a postnuclear supernatant from Vero homogenates was optimized in such a way that the dense organelles such as ER (defined by KCN-resistant NADH-oxidoreductase activity) and lysosomes (defined by glucosaminidase activity) ran close to the bottom of the gradient, whereas the less dense organelles, i.e., trans-Golgi (defined by galactosyltransferase activity) and plasma membrane (defined by alkaline phosphatase activity) ran close to the top of the gradient. The separation was optimal with $10.5 \%$ Percoll (Fig. 2 a). 


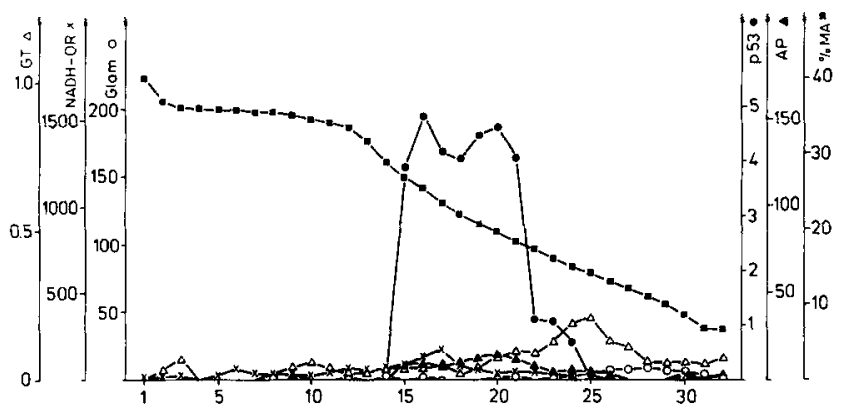

Figure 3. Distribution of p53 and marker enzymes on a continuous Metrizamide gradient. Postnuclear supernatants of Vero cells were fractionated on a $10.5 \%$ Percoll gradient as shown in Fig. 2. Fractions 6-14 (pool in Fig. 2) were further fractionated on a 5-30\% Metrizamide gradient. The gradient was divided into 32 fractions of $1.05-\mathrm{ml}$ beginning at the bottom. Symbols and activities are as in Fig. 2; filled squares indicate the concentration of Metrizamide (wt/wt)

On such gradients p53 was found in the center as a broad peak when analyzed by immunoblotting of gradient fractions with a polyclonal antibody raised against the denatured p53.

Fractions 6-14 were pooled and served as starting material for the second purification step. For this purpose the pooled fractions were subjected to equilibrium flotation on a discontinuous Metrizamide gradient that was optimized according to the sedimentation properties of the p53 compartment on continuous Metrizamide gradients (Fig. 3). The 18.5\%/27\% interphase was collected and subjected to a high-speed centrifugation in PBS. This final fraction was designated F3. The marker characterization of this fraction is given in Tables I and II. To measure quantitatively p53 in subcellular fractions of Vero cells a dot-blot procedure using mAb G1/93 was developed (see Materials and Methods for detail). Based on this determination F3 was found to be enriched 40.9-fold in p53 with a yield of $29 \%$. None of the other organelle markers were enriched with the exception of the ER marker $\mathrm{KCN}$-resistant NADH-oxidoreductase which was twofold enriched. The recovery for all the markers was between 69 and $108 \%$. Based on this biochemical analysis we conclude that the procedure depicted in Fig. 1 efficiently separates the p53 compartment from trans-Golgi, plasma membrane, lysosomes, and ER.

Table I. Specific Activities and Enrichment Factors of p53 and Marker Enzymes in F3

\begin{tabular}{lccc}
\hline & \multicolumn{2}{c}{ Specific activity* } & \\
\cline { 2 - 3 } & Homogenate & F3 & F3 enrichment factor \\
\hline $\begin{array}{l}\text { 53-kD protein } \\
\text { Glucosaminidase }\end{array}$ & $0.9 \pm 0.5$ & $33.2 \pm 13.1$ & $40.9 \pm 12.2$ \\
$\begin{array}{c}\text { Galactosyl- } \\
\text { transferase }\end{array}$ & $0.11 \pm 0.02$ & $0.07 \pm 0.03$ & $0.6 \pm 0.2$ \\
$\begin{array}{c}\text { KCN-resistant } \\
\text { NADH oxido- }\end{array}$ & $331 \pm 72$ & $688 \pm 293$ & $2.1 \pm 0.8$ \\
$\begin{array}{c}\text { reductase } \\
\text { Alkaline } \\
\text { phosphatase }\end{array}$ & $11.7 \pm 2.1$ & $5.2 \pm 0.9$ & $0.4 \pm 0.1$ \\
\hline
\end{tabular}

The numbers indicate means \pm 1 SD of six independent experiments.

* The values are given in arbitrary units/milligram protein for p53 and milliunits/milligram protein for the enzymes.
Table II. Yield and Recovery of Marker Enzymes in a Fraction Enriched in p53 (F3)

\begin{tabular}{lcr}
\hline & Total $^{*}$ & \multicolumn{1}{c}{ F3 } \\
\hline Protein & $87 \pm 11$ & $0.8 \pm 0.2$ \\
53-kD protein & $84 \pm 8$ & $28.6 \pm 7.7$ \\
Glucosaminidase & $99 \pm 12$ & $0.3 \pm 0.1$ \\
Galactosyltransferase & $108 \pm 13$ & $0.5 \pm 0.2$ \\
KCN-resistant NADH & & \\
$\quad$ oxidoreductase & $69 \pm 2$ & $1.9 \pm 0.7$ \\
Alkaline phosphatase & $82 \pm 7$ & $0.3 \pm 0.1$
\end{tabular}

The values are given as percentage of the amount determined in the homogenate and represent means \pm 1 SD of six independent experiments. * Sum of the amount recovered in each fraction.

\section{Morphological Characterization of the Isolated p53 Compartment}

Transmission EM was performed to characterize morphologically the F3 fraction (Fig. 4). The fraction was found to be almost exclusively composed of numerous smooth-surfaced membrane vesicles. Many vesicles with an average diameter of $89 \pm 18 \mathrm{~nm}$ (mean $\pm 1 \mathrm{SD}, n=95$ ) exhibited an electron-dense core, whereas some larger vesicles were empty. The dense core structures which probably represent vesicles carrying secretory products may correspond to the dense-core vesicles that stain positive with the anti-p53 antibody in ultrathin cryosections of various cells (Schweizer et al., 1988, 1990), whereas the larger vesicles may originate from the tubular elements of the $\mathrm{p} 53$ compartment. The vesicles had no obvious electron-dense coat but many of them showed a dark staining-limiting membrane. It is worth noting that the F3 fraction was free from drumstick-like profiles characteristic for Golgi cisternae (Stieger et al., 1988) and from endosomes (Gruenberg et al., 1989; McDowall et al., 1989) which can be expected to remain intact, at least in part, considering the rather mild homogenization conditions used. These conditions were identical to those used for the isolation of the Golgi apparatus in Stieger et al. (1988). Furthermore, our previous experiments have shown that endosomes as defined by a 15-min uptake of horseradish peroxidase display low density on Percoll gradients, a density that was even slightly lower than that of the plasma membrane (Matter et al., 1990).

\section{Polypeptide Composition of the Isolated p53 Compartment}

Comparative SDS-PAGE of subcellular fractions (Fig. 5) revealed the enrichment of at least 16 bands when compared with the homogenate (compare lanes 1 and 6 ). These proteins display molecular masses between 23 and $149 \mathrm{kD}$. The position of p53 was identified by immunoblotting (not shown). This protein pattern is similarly complex as that of purified Golgi apparatus (Malhotra et al., 1989) but less complex than that of rough endoplasmic reticulum (AmarCostesec et al., 1988). These data suggest that the F3 fraction contains a distinct set of proteins.

\section{Relationship of the Isolated p53 Compartment to Rough ER and cis-Golgi}

Among the best characterized proteins known to be restricted to the rough ER are the integral membrane proteins 

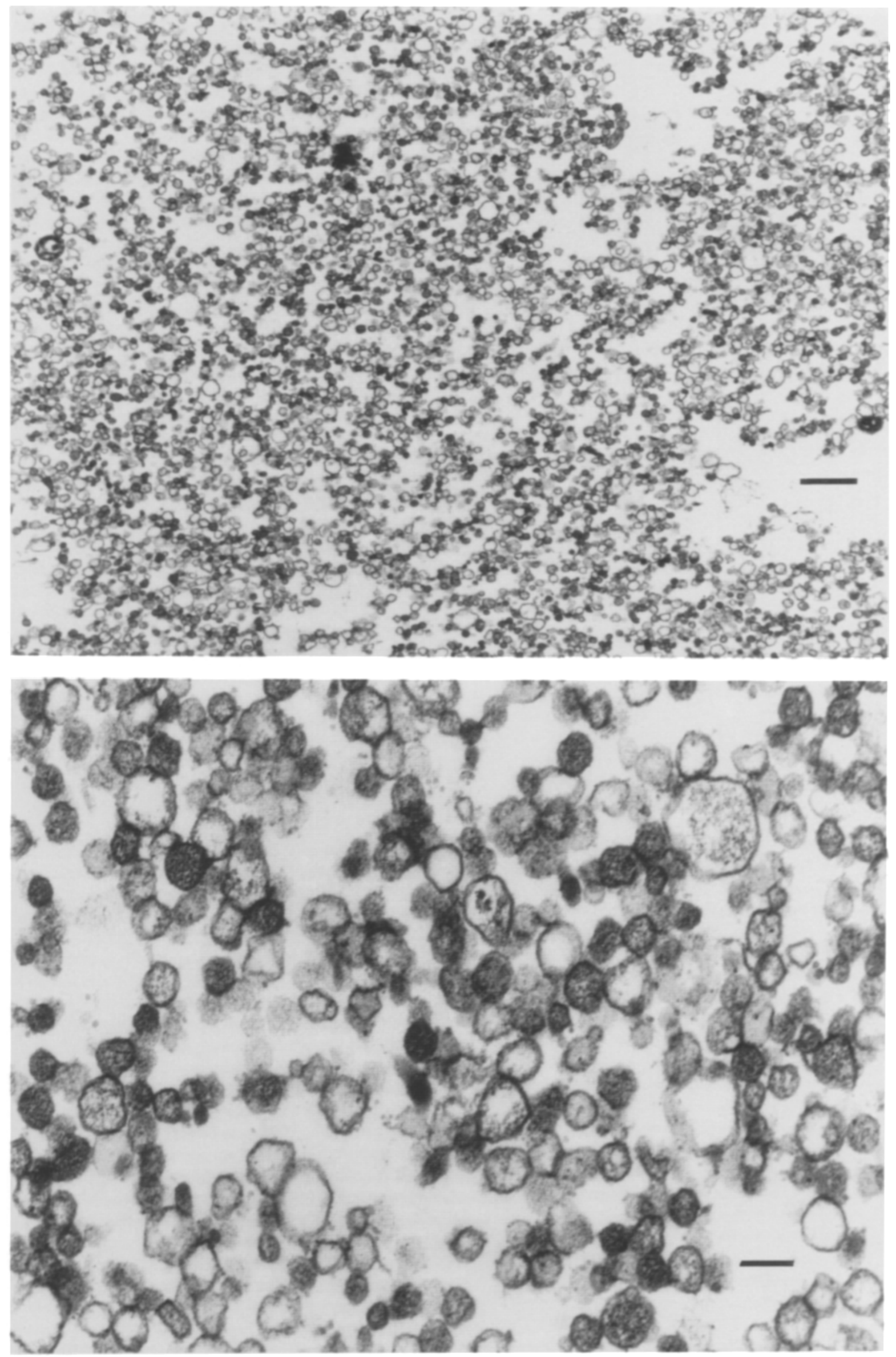

Figure 4. Representative transmission electron micrograph of the p53 compartment fraction F3. Bars: (top) $0.83 \mu \mathrm{m} ;($ bottom) $0.18 \mu \mathrm{m}$. 


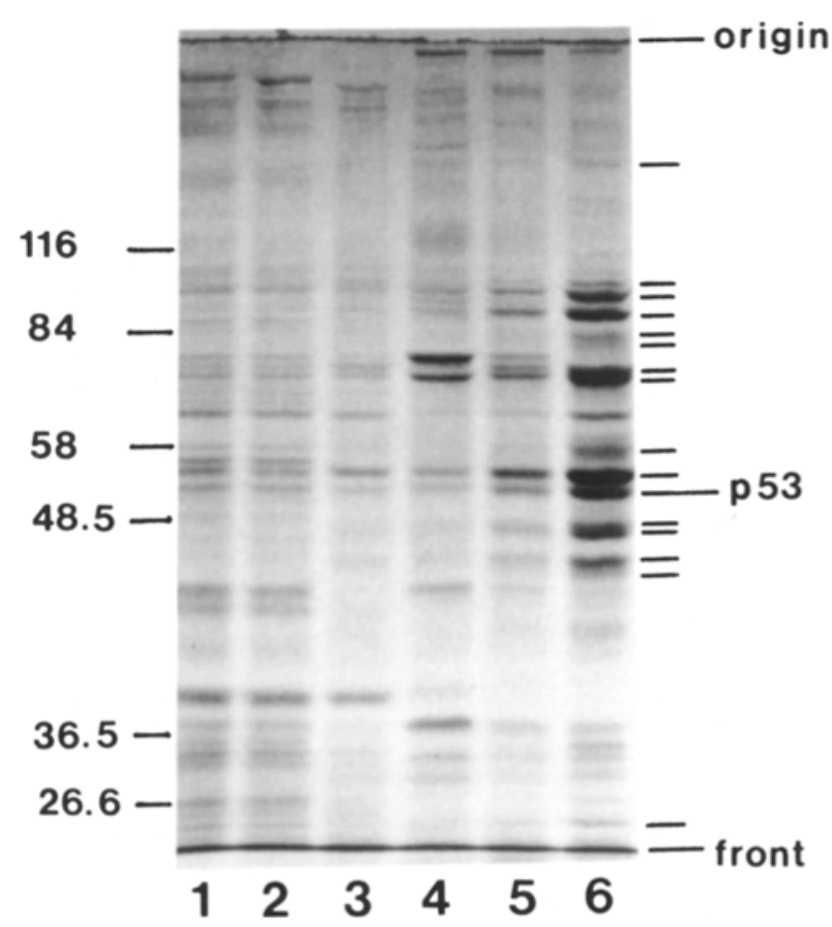

Figure 5. Comparative polypeptide composition of subcellular fractions. Aliquots of subcellular fractions $(100 \mu \mathrm{g}$ protein/lane) were subjected to SDS-PAGE $(8.5 \%$ gel) and stained with Coomassie brilliant blue. Lane 1, homogenate; lane 2, postnuclear supernatant; lane 3, pooled fractions 6-14 of Percoll gradient; lane 4, F1 (see Fig. 1), lane 5, F2 (see Fig. 1), and lane 6, F3. Molecular weights were determined from a set of markers (not shown). The bars at the right margin indicate protein bands specifically enriched in the F3 fraction.

ribophorin I (65 kD) and II (two protein subunits, $63 \mathrm{kD}$ ) (Kreibich et al, 1978; Hortsch et al., 1986; Crimaudo et al., 1987), which were initially proposed to mediate the attachment of ribosomes but whose function is still unclear. Soluble resident ER proteins include the 57- $\mathrm{kD}$ enzyme protein disulfide isomerase, which catalyzes the rearrangement of disulfide bonds (Freedman, 1984; Edman et al., 1985) and the 78-kD protein BIP (glucose-regulated protein 78) (Bole et al., 1986, 1989; Munro and Pelham, 1986), which may function in protein folding and oligomerization. To investigate to what extent the isolated p53 compartment is related to the rough ER, Western blots of Vero homogenates and corresponding F3 fractions having equal protein amounts were probed with $\mathrm{mAbs}$ against ribophorin I (Fig. 6, lanes 1 and 2) and II (Fig. 6, lanes 3 and 4) and with polyclonal antibodies to protein disulfide isomerase (Fig. 6, lanes 5 and 6) and BIP (Fig. 6, lanes 7 and 8). Quantification of the immunoblots by densitometric scanning gave the following enrichment factors (mean $\pm 1 \mathrm{SD}, n=3$ ). Ribophorin I: 1.4 \pm 0.4 ; ribophorin II: $1.1 \pm 0.1$; protein disulfide isomerase: $1.8 \pm 0.3$; BIP: $2.8 \pm 0.4$. Thus, the markers were, if at all, only slightly enriched comparable to the enrichment of the ER enzyme KCN-resistant NADH oxidoreductase. These results suggest that we have largely separated the p 53 compartment from the rough ER.

To date, no accepted cis-Golgi marker protein is known whose localization has been confirmed by immunoelectron microscopy. Candidate cis-Golgi markers as deduced from biochemical studies include Golgi $\alpha$-mannosidase IA (Tabas and Kornfeld, 1979; Dunphy and Rothman, 1983), $\mathrm{N}$-acetylglucosaminylphosphotransferase (phosphotransferase) (Goldberg and Kornfeld, 1983; Kornfeld and Kornfeld, 1985) and the uncovering enzyme $\mathrm{N}$-acetylglucosamine 1-phosphodiester- $\alpha-N$-acetylglucosaminidase (Goldberg and Kornfeld, 1983; Kornfeld and Kornfeld, 1985; Lazzarino and Gabel, 1988,1989 ). The latter two enzymes are responsible for the formation of the mannose-6-phosphate targeting signal of lysosomal enzymes (Kornfeld and Mellman, 1989). Rabbit antibodies against rat liver Golgi mannosidase IA (Tulsiani and Touster, 1988) were unable to recognize the corresponding enzyme in the monkey-derived Vero cells. Measurements of this enzyme activity are complicated by possible interference with other mannosidases (Bishoff and Kornfeld, 1983; Bishoff et al., 1986). We decided therefore to measure the distribution of phosphotransferase and uncovering enzyme activities in the fractions of the Percoll gradient (Fig. $2 b$ ) and in the F3 fraction (Table III) to investigate the relationship of the p53 compartment and cis-Golgi. Both enzymes comigrated to the same position on the Percoll gradient close to the galactosyltransferase peak. The peak fractions of both phosphotransferase and uncovering enzyme were localized to one fraction denser than the peak of the trans-Golgi marker galactosyltransferase. There was also some trailing of the phosphotransferase and uncovering enzyme activities into the broad p53 peak. Table III shows that in the F3 fraction phosphotransferase was enriched five- to sixfold and uncovering enzyme only two- to three fold. This result suggests that the major localization of phosphotransferase and the uncovering enzyme in Vero cells is not the p53 intermediate compartment but most likely the cis-Golgi. The p53 compartment therefore can also be separated from the cis-Golgi elements.

\section{Discussion}

The recently described $53-\mathrm{kD}$ protein has been shown to be a marker for an ER-Golgi intermediate of the exocytic transport pathway in Vero cells (Schweizer et al., 1988, 1990). This p53 compartment has now been purified by a combination of Percoll and Metrizamide gradient centrifugation resulting in an efficient separation from ER, Golgi, lysosomes and plasma membrane markers and a 41-fold enrichment of p53. Despite this considerable enrichment we are aware of the possibility that further purification may be required before the $\mathrm{p} 53$ compartment can be considered free of any contaminating membranes for which there are no accepted markers. As soon as sequence information of the cytoplasmic domain of p53 is available antibody tools can be generated for a more complete purification of the intermediate compartment by immunoaffinity procedures. Nevertheless, the achieved degree of purification already allows important conclusions concerning the relationship of the p53 compartment with its neighbour organelles, the ER and the Golgi apparatus as discussed below.

Electron micrographs of the isolated fraction demonstrate the presence of numerous smooth vesicles. Many of the vesicles with an average diameter of $89 \mathrm{~nm}$ exhibit an electron dense interior and resemble the vesicular structures stained 

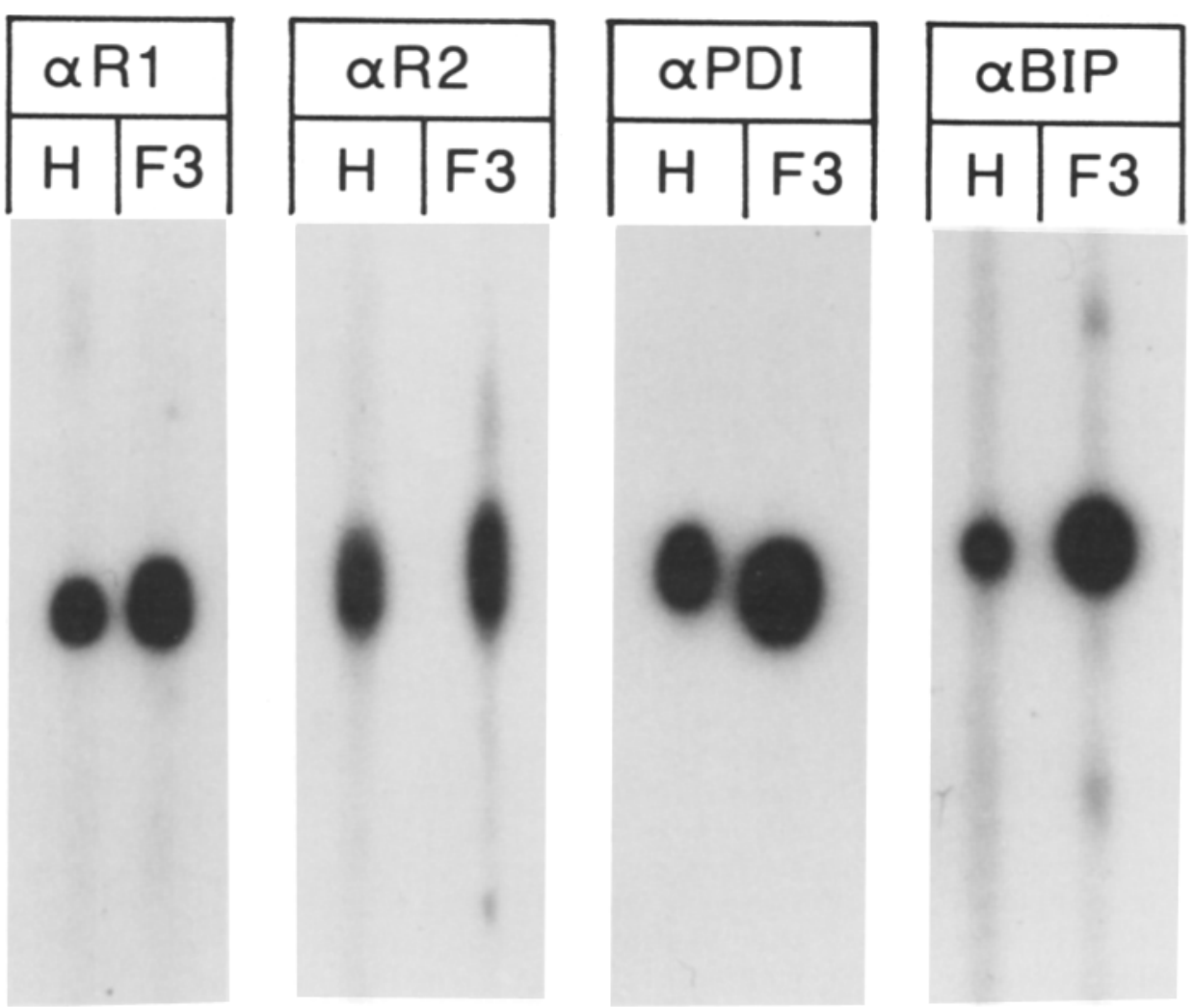

Figure 6. Immunoblot analysis of homogenate $(\mathrm{H})$ and $\mathrm{F} 3$ fractions with antibodies to rough ER markers (autoradiograms). Homogenate and F3 were prepared as described and equal protein amounts $(22 \mu \mathrm{g} / \mathrm{mm}$ gel width) were subjected to SDS-PAGE (8.5\% gel) and immunoblotting. Individual nitrocellulose strips were probed with a mAb against ribophorin I ( $\alpha R I)$; a mAb against ribophorin II $(\alpha R 2)$; a polyclonal antibody against protein disulfide isomerase $(\alpha P D I)$; or a polyclonal antibody against protein BIP $(\alpha B I P)$. Only the area with the immunoreaction is shown. BIP was consistently more enriched in the F3 fraction that ribophorin I, ribophorin II or disulfide isomerase. The apparent shift of the $\alpha$ PDI immunoreaction in F3 versus homogenate is due to nonperfect alignment of the two nitrocellulose strips in the film cassette. Ribophorin II is composed of two subunit proteins (Crimaudo et al., 1987), which were not resolved as two discrete bands in our blotting procedure at the exposition time used. with the anti-p53 antibody on cryosections in situ. However, the thin (apparently nonclathrin) coat which is present on at least some p53-bearing vesicles in situ (Schweizer et al., 1988 ) could not unambiguously be detected in the isolated fraction. This may reflect some technical problems in the preparation of the isolated fraction for EM or represent a loss of the coat. Jamieson and Palade (1967) have described smooth surface vesicles on the cis side of the Golgi apparatus in situ. In guinea pig pancreatic cells these vesicles were found to have a diameter of about $50 \mathrm{~nm}$ and were covered by a fine fibrillar coat. Transition vesicles between ER and Golgi have also been depicted by Morré and colleagues (Nowack et al., 1987) as electron dense structures with a naplike surface coat and a diameter which varies from 55 to $88 \mathrm{~nm}$ according to the conditions used (Morré et al., 1989). The

Table III. Specific Activities and Enrichment Factors of Putative cis-Golgi Markers in F3

\begin{tabular}{llccc}
\hline & & \multicolumn{2}{c}{ Specific activity* } & \\
\cline { 3 - 4 } & & Homogenate & F3 & F3 enrichment factor \\
\hline Phospho- & Exp. 1 & 110 & 596 & 5.4 \\
transferase & Exp. 2 & 116 & 703 & 6.1 \\
Uncovering & Exp. 1 & 863 & 2,490 & 2.9 \\
enzyme & Exp. 2 & 1,652 & 4,000 & 2.4 \\
\hline
\end{tabular}

* The values are given in milliunits/milligram protein; two independent experiments. purification of these vesicular intermediates from a cell-free transport system has been reported (Paulik et al., 1988). Moreover, Lodish et al. (1987) described the isolation of a low-density membrane fraction that has some of the biochemical characteristics expected for ER to Golgi transport vesicles. Recently a vesicular ER-Golgi transport intermediate has also been isolated from yeast (Groesch et al., 1990). This intermediate contained a post-ER/pre-Golgi form of pro- $\alpha$-factor. All these preparations, however, lack extensive purification and biochemical characterization rendering a comparison with the present F3 fraction impossible.

Investigation of the polypeptide composition of the isolated p53 compartment revealed several prominent bands which were enriched when compared to the homogenate. We do not know the identity of these proteins yet. Importantly, the protein pattern is significantly different from that described for isolated Golgi membranes (Malhotra et al., 1989) or rough ER (Amar-Costesec et al., 1988) suggesting that the isolated fraction has unique properties not shared by its neighbor organelles. Compared with the p53-compartment the polypeptide composition of the $106 \mathrm{~nm}$ non-clathrin-coated intra-Golgi vesicles (Malhotra et al., 1989) as well as of the $84 \mathrm{~nm}$ noncoated post-Golgi vesicles (de Curtis and Simons, 1989) is less complex in nature. Assuming that protein transport from ER to Golgi is mediated by transport vesicles only and that no tubular intermediate compartment would exist this comparison would suggest that the fraction we have isolated is still contaminated with unknown membranes. An alternative view, and the one we prefer, is that a tubular intermediate compartment exists. This notion re- 
sides on the following: first, mAb G1/93 against p53 labels tubular and vesicular profiles at the ultrastructural levels in situ (Schweizer et al., 1988). Second, if the intracellular protein transport to the Golgi apparatus of VSV G protein is arrested at $15^{\circ} \mathrm{C}$, the $\mathrm{G}$ protein accumulates in tubular and vesicular profiles close to the Golgi apparatus (Schweizer et al., 1990), suggesting that the tubular elements are part of the exocytic pathway. For a membrane compartment, a polypeptide pattern of the complexity we have obtained is not surprising and may largely reflect the protein complement of the intermediate compartment itself. This notion is supported by recent results showing that the majority of $\mathrm{mAbs}$ generated against the isolated F3 fraction exhibit immunofluorescence patterns that resemble those obtained with the G1/93 mAb against p53 (Schweizer, A., unpublished).

The isolated p53 compartment was further characterized with respect to its relationship to the rough ER. The two rough ER membrane markers ribophorin I and II and the KDEL-bearing luminal rough ER markers protein disulfide isomerase and BIP were largely separable from the intermediate p53 compartment. This feature suggests that the intermediate compartment may be considered a separate organelle. This notion is further supported by the specific association of a unique low-molecular weight GTP-binding protein related to rab 2 with the p53 compartment in situ (Chavrier et al., 1990). Whether the intermediate compartment is nevertheless connected with the rough ER by membrane continuities as the smooth ER in hepatocytes or whether the two compartments are connected by a vesicular pathway remains to be shown by detailed morphological studies at the ultrastructural level. Since protein disulfide isomerase and BIP have access to a post-ER compartment and are thought to recycle back to the ER by means of the KDEL mechanism (Pelham, 1988) it is not absolutely clear if the slight enrichment of these two proteins in the purified F3 fraction reflects the specific origin of this compartment or simply minor cross-contamination with ER. What is the relationship of the p53 intermediate compartment and the cis-Golgi apparatus? Morphologically, what is normally considered the cis-most element of the Golgi apparatus appears as a fenestrated cisterna or network in the transmission electron microscope (Rambourg and Clermont, 1990). However, some authors have described direct membrane continuities between cis-Golgi cisternae and rough ER (Lindsey and Ellisman, 1985), which complicates the structural definition of cis-Golgi. Likewise, in functional terms, the definition of cis-Golgi is not clear either because none of the biochemically established putative cis-Golgi enzyme markers have been localized yet by immunoelectron microscopy. In the absence of a firm structural-functional relationship, the definition of cis-Golgi is tentative. For the present study, we have considered the uncovering enzyme a marker for the cis-Golgi.

The initial phosphorylation of lysosomal enzymes by phosphotransferase has been proposed to occur in a post-ER pre-Golgi site (Pelham, 1988; Lazzarino and Gabel, 1988, 1989), while the conversion of monophosphorylated species to diphosphorylated forms by phosphotransferase and the hydrolysis of diesters by the uncovering enzyme is believed to occur within the cis-Golgi (Lazzarino and Gabel, 1988, 1989; Kornfeld and Mellman, 1989). On our Percoll gradients the main peaks of phosphotransferase and uncovering enzyme were unseparable from one another but they did not colocalize with the p53 peak. In the final F3 fraction the relative enrichment was 5 to 6 for phosphotransferase and 2 to 3 for the uncovering enzyme, considerably less than the enrichment for p53. Given the above series of phosphorylation events one possible explanation for these results is that phosphotransferase has a biphasic distribution with a minor portion in the p53 compartment and the major portion in the cisGolgi. Alternatively, both enzymes may be localized beyond the intermediate compartment in Vero cells and the activity in the F3 fraction may just reflect cross-contamination with elements of the cis-Golgi. It is worth noting, however, that the enrichment in F3 was always consistently higher for phosphotransferase than for the uncovering enzyme.

On the Percoll gradient there was some trailing of p53 into the main phosphotransferase/uncovering enzyme peak that may be related to the finding in other human cells that the first fenestrated cis-Golgi cisterna showed weak immunoreactivity with the mAb against p53 (Schweizer et al., 1988; Chavrier et al., 1990). P53 may have access to the cis-Golgi and there is immunofluorescence evidence for recycling of p53 to the ER in human M1 cells (Lippincott-Schwartz et al., 1990). Therefore, $p 53$ cannot a priori be considered an absolute marker for the ER-Golgi intermediate compartment in all cell types. In Vero cells, however, the majority of p53 resides in the intermediate compartment as assessed by labeling studies with mAb Gl/93 (Schweizer et al., 1990). This observation was in fact the basis for using Vero cells in the present study. Collectively, the results suggest to us that we have largely separated the $\mathbf{p} 53$ compartment from cis-Golgi elements defined by the uncovering enzyme. As with the rough ER this does not necessarily imply absence of membrane continuities. It should be noted, however, that the p53 compartment behaves differently from cis-Golgi (defined by the putative cis-Golgi marker mannosidase IA and the cismedial Golgi marker mannosidase II) in cells that have been treated with organelle perturbants such as brefeldin A or nocodazole (Lippincott-Schwartz et al., 1989, 1990).

Using semi-intact cells to reconstitute ER to Golgi transport in a cell-free system, Balch and co-workers established a number of biochemical requirements for ER to cis-Golgi protein transport (Beckers et al., 1987; Balch, 1989; Beckers and Balch, 1989). In particular they postulate the existence of an intermediate compartment where transport is inhibited by GTP $\gamma$, EGTA, or $N$-ethylmaleimide. It will be of interest to study the functional properties of the isolated p53 compartment in respect to these findings.

Given the successful isolation of the p53 intermediate compartment it should now be possible to study its functions in more detail. Candidate functions include all processes which have been assigned to a post-ER pre-Golgi site, such as the addition of $\mathrm{N}$-acetylgalactosamine to serine and threonine residues of glycoproteins (Tooze et al., 1988), fatty acylation of proteins (Rizzolo et al., 1985; Rizzolo and Kornfeld, 1988, Bonatti et al., 1989) and binding of endogenous antigens to class I histocompatibility antigens (Nuchtern et al., 1989; Yewdell and Bennik, 1989; Cox et al., 1990). An additional possible function of the p53 compartment might be the salvage of luminal ER proteins (Warren, 1987; Pelham, 1989). If this is the case the recently identified KDEL receptor (Vaux et al., 1990) should reside in the isolated p53 compartment. 
We thank Dr. Thomas Baechi for performing the electron microscopy and Dr. Stuart Kornfeld for helpful discussion. We are also indebted to Dr. Stephen Fuller for kindly providing antibodies to protein disulfide isomerase and BIP, Dr. David Meyer for antibodies against ribophorin I and II, and Dr. Oscar Touster for antibodies against mannosidase IA.

This work was supported by the Swiss National Science Foundation. C. M. Ketcham was supported by American Cancer Society Fellowship PF-4017.

Received for publication 18 September 1990 and in revised form 22 November 1990

\section{References}

Amar-Costesec, A., M. Hortsch, and C. Turu. 1988. A membrane preparation that contains proteins characteristic of rough endoplasmic reticulum. Biol Cell. 62:281-288.

Balch, W. E. 1989. Biochemistry of interorganelle transport. J. Biol. Chem 264:16965-16968.

Balch, W. E., and J. E. Rothman. 1985. Characterization of protein transport between successive compartments of the Golgi apparatus: asymmetric properties of donor and acceptor activities in a cell-free system. Arch. Biochem. Biophys. 240:413-425.

Beckers, C. J. M., and W. E. Balch. 1989. Calcium and GTP: essential components in vesicular trafficking between the endoplasmic reticulum and the Golgi apparatus. J. Cell Biol. 108:1245-1256.

Beckers, C. J. M., D. S. Keller, and W. E. Balch. 1987. Semi-intact cells permeable to macromolecules: use in reconstitution of protein transport from the endoplasmic reticulum to the Golgi apparatus. Cell. 50:525-534.

Bishoff, J., and R. Kornfeld. 1983. Evidence for an $\alpha$-mannosidase in endoplas mic reticulum of rat liver. J. Biol. Chem. 258:7907-7910.

Bishoff, J., L. Liscum, and R. Kornfeld. 1986. The use of 1-deoxymannojirimycin to evaluate the role of various $\alpha$-mannosidases in oligosaccharide processing in intact cells. J. Cell Biol. 261:4766-4774.

Bole, D. G., L. M. Hendershott, and J. F. Kearney. 1986. Posttranslational association of immunoglobulin heavy-chain binding-protein with nascent heavy chains in non-secreting and secreting hybridomas. J. Cell Biol. 102:1558-1566.

Bole, D. G., R. Dowin, M. Doriaux, and J. D. Jamieson. 1989. Immunocytochemical localization of BIP to the rough endoplasmic reticulum: evidence for protein sorting by selective retention. J. Histochem. Cytochem. 37: 1817-1823.

Bonatti, S., G. Migliaccio, and K. Simons. 1989. Palmitylation of viral membrane glycoproteins takes place after exit from the ER. J. Biol. Chem. 264:12590-12595.

Chavrier, P., R. G. Parton, H.-P. Hauri, K. Simons, and M. Zerial. 1990. Localization of low molecular weight GTP-binding proteins to exocytic and endocytic compartments. Cell. 62:317-329.

Cox, J. H., J. W. Yewdell, L. C. Eisenlohr, P. R. Johnson, and J. R. Bennik. 1990. Antigen presentation requires transport of MHC class I molecules from endoplasmic reticulum. Science (Wash. DC). 247:715-718.

Crimaudo, C., M. Hortsch, H. Gausepohl, and D. Meyer. 1987. Human ribophorins I and II: the primary structure and membrane topology of two highly conserved rough endoplasmic reticulum-specific glycoproteins. EMBO (Eur. Mol. Biol. Organ.) J. 6:75-82

De Curtis, I., and K. Simons. 1989. Isolation of exocytic carrier vesicles from BHK cells. Cell. 58:719-727.

Dunphy, W. G., and J. E. Rothman. 1983. Compartmentalization of asparagine-linked oligosaccharide processing in the Golgi apparatus. J. Cell Biol. 97:270-275.

Edman, J. C., J. Ellis, R. W. Blacher, R. W. Roth, and W. J. Rutter. 1985. Sequence of protein disulphide isomerase and implication of its relationship to thioredoxin. Nature (Lond.). 317:267-270.

Freedman, R. B. 1984. Native disulphide bond formation in protein biosynthe sis: evidence for the role of protein disulphide isomerase. Trends Biochem. Sci. 9:438-441.

Goldberg, D. E., and S. Kornfeld. 1983. Evidence for extensive subcellular organization of asparagine-linked oligosaccharide processing and lysosomal enzyme phosphorylation. $J$. Biol. Chem. 258:3159-3165.

Gorr, S.-U., B. Stieger, J. A. M. Fransen, M. Kedinger, A. Marxer, and H.-P. Hauri. 1988. A novel marker glycoprotein for the microvillus membrane of surface colonocytes of rat large intestine and its presence in small-intestinal crypt cells. J. Cell Biol. 106:1937-1946.

Groesch, M. E., H. Ruohola, R. Bacon, G. Rossi, and S. Ferro-Novick. 1990. Isolation of a functional vesicular intermediate that mediates ER to Golgi transport in yeast. J. Cell Biol. 111:45-53.

Gruenberg, J., G. Griffiths, and K. Howell. 1989. Characterization of the early endosome and putative endocytic carrier vesicles in vivo and with an assay of vesicle fusion in vitro. $J$. Cell Biol. 108:1301-1316.

Hauri, H.-P., and K. Bucher. 1986. Immunoblotting with monoclonal antibod ies: importance of the blocking solution. Anal. Biochem. 159:386-389.

Hawkes, R., E. Niday, and J. Gordon. 1982. A dot-immunobinding assay for monoclonal and other antibodies. Anal. Biochem. 119:142-147.

Hortsch, M., D. Avossa, and D. J. Meyer. 1986. Characterization of secretory protein translocation: ribosome-membrane interaction in ER. J. Cell Biol. 103:241-253.

Jamieson, J. D., and G. E. Palade. 1967. Intracellular transport of secretory proteins in the pancreatic exocrine cell. I. Role of peripheral elements of the Golgi complex. J. Cell Biol. 34:577-596.

Kornfeld, R., S. Kornfeld. 1985. Assembly of asparagine-linked oligosaccharides. Annu. Rev. Biochem. 54:631-634.

Kornfeld, S., and I. Mellman. 1989. The biogenesis of lysosomes. Annu. Rev. Cell. Biol. 5:483-525.

Kreibich, G., B. L. Ulrich, and D. D. Sabatini. 1978. Proteins of rough microsomal membranes related to ribosome binding. I. Identification of ribophorins I and II, membrane proteins characteristic of rough microsomes. J. Cell Biol. 77:464-487.

Laemmli, U. K. 1970 . Cleavage of structural proteins during assembly of the head of bacteriophage T4. Nature (Lond.). 227:680-685

Lang, L., and S. Kornfeld. 1984. A simplified procedure for synthesizing large quantities of highly purified uridine $\left[\beta{ }^{32} \mathrm{P}\right]$ diphospho-N-acetylglucosamine. Anal. Biochem. 140:264-269.

Lang, L., R. Couso, and S. Kornfeld. 1986. Glycoprotein phosphorylation in simple eucaryotic organisms. Identification of UDP-GlcNac:glycoprotein $\mathrm{N}$-acetylglucosamine-1-phosphotransferase activity and analysis of substrate specificity. J. Biol. Chem. 261:6320-6325

Lazzarino, D. A., and C. A. Gabel. 1988. Biosynthesis of the mannose 6-phosphate recognition marker in transport-impaired mouse lymphoma cells: demonstration of a two-step phosphorylation. J. Biol. Chem. 263:10118-10126.

Lazzarino, D. A., and C. A. Gabel. 1989. Mannose processing is an important determinant in the assembly of phosphorylated high mannose-type oligosaccharides. J. Biol. Chem. 264:5015-5023.

Lindsey, J. D., and M. H. Ellisman. 1985. The neuronal endomembrane system. I. Direct links between rough ER and the cis element of the Golgi apparatus. J. Neurosci. 5:3111-3123.

Lippincott-Schwartz, J., L. Yuan, J. S. Bonifacino, and R. D. Klausner. 1989. Rapid redistribution of Golgi proteins into the ER in cells treated with brefeldin A: evidence for membrane cycling from the Golgi to the ER. Cell. 56:801-813.

Lippincott-Schwartz, J., J. G. Donaldson, A. Schweizer, E. G. Berger, H.-P. Hauri, L. C. Yuan, and R. D. Klausner. 1990. Microtubule-dependent retrograde transport of proteins into the ER in the presence of brefeldin A reveals an ER recycling pathway. Cell. 60:821-836.

Lodish, H. F., N. Kong, S. Hirani, and J. Rasmussen. 1987. A vesicular intermediate in the transport of hepatoma secretory proteins from the rough ER to the Golgi complex. J. Cell Biol. 104:221-230.

Malhotra, V., T. Serafini, L. Orci, J. C. Shepherd, and J. E. Rothman. 1989. Purification of a novel class of coated vesicles mediating biosynthetic protein transport through the Golgi stack. Cell. 58:329-336.

Matter, K., B. Stieger, J. Klumperman, L. Ginsel, and H. P. Hauri. 1990. Endocytosis, recycling, and lysosomal delivery of brush border hydrolases in cultured human intestinal epithelial cells (Caco-2). J. Biol. Chem. 265: 3503-3512.

McDowall, A., J. Gruenberg, K. Roemisch, and G. Griffiths. 1989. The structure of organelles of the endocytic pathway in hydrated cryosections of cultured cells. Eur. J. Cell Biol. 49:281-294.

Morre, D. J., N. Minnifield, and M. Paulik. 1989. Identification of the $16^{\circ} \mathrm{C}$ compartment of the ER in rat liver and cultured hamster kidney cells. Biol. Cell. 67:51-60.

Munro, S., and H. R. B. Pelham. 1987. A C-terminal signal prevents secretion of luminal ER proteins. Cell. 48:899-907.

Nowack, D. D., D. M. Morre, M. Paulik, T. W. Keenen, and D. J. Morré 1987. Intracellular membrane flow: reconstitution of transitional vesicle formation and function in a cell-free system. Proc. Natl. Acad. Sci. USA. 84:6098-6102.

Nuchtern, J. G., J. S. Bonifacino, W. E. Biddison, and R. D. Klausner. 1989. Brefeldin A implicates egress from endoplasmic reticulum in class I restricted antigen presentation. Nature (Lond.). 339:223-226.

Palade, G. E. 1975. Intracellular aspects of the process of protein transport Science (Wash. DC). 189:347-358.

Paulik, M., D. D. Nowack, and D. J. Morré. 1988. Isolation of a vesicular intermediate in the cell-free transfer of membrane from transitional elements of the endoplasmic reticulum to Golgi apparatus cisternae of rat liver. J. Biol. Chem. 263:17738-17748

Pelham, H. R. B. 1988. Evidence that luminal ER proteins are sorted from secreted proteins in a post-ER compartment. EMBO (Eur. Mol. Biol. Organ.) J. 7:914-918.

Pelham, H. R. B. 1989. Control of protein exit from the endoplasmic reticulum. Annu. Rev. Cell Biol. 5:1-23.

Rambourg, A., and Y. Clerment. 1990. Three-dimensional electron micros copy: structure of the Golgi apparatus. Eur. J. Cell Biol. 51:189-200.

Reitman, M. L., L. Lang, and S. Kornfeld. 1984. UDP-N-acetylglucosamine: lysosomal enzyme N-acetylglucosamine-1-phosphotransferase. Methods Enzymol. 107:163-172.

Rizzolo, L. J., and R. Kornfeld. 1988. Posttranslational protein modification in the endoplasmic reticulum. Demonstration of fatty acylase and deoxymannojirimycin-sensitive alpha-mannosidase activities. $J$. Biol. Chem. 5:95209525 . 
Rizzolo, L. J., J. Finidori, A. Gonzalez, M. Arpin, I. E. Ivanov, M. Adesnik, and D. D. Sabatini. 1985. Biosynthesis and intracellular sorting of growth hormone-viral envelope glycoprotein hybrids. J. Cell Biol. 101:1351-1562.

Saraste, J., and E. Kuismanen. 1984. Pre- and post-Golgi vacuoles operate in the transport of Semliki forest virus membrane glycoproteins to the cell surface. Cell. 38:535-549.

Scalera, V., C. Storelli, C. Storelli-Joss, W. Haas, and H. Murer. 1980. A simple fast method for the isolation of basolateral plasma membrane from ratsmall-intestinal epithelial cells. Biochem. J. 186:177-181.

Schweizer, A., J. A. M. Fransen, T. Baechi, L. Ginsel, and H.-P. Hauri. 1988. Identification, by a monoclonal antibody, of $53-\mathrm{kD}$ protein associated with a tubulovesicular compartment at the cis-side of the Golgi apparatus. J. Cell Biol. 107:1643-1653.

Schweizer, A., J. Fransen, K. Matter, T. E. Kreis, L. Ginsel, and H. P. Hauri. 1990. Identification an intermediate compartment involved in protein transport from ER to Golgi apparatus. Eur. J. Cell Biol. 53:185-196.

Sottocasa, G. L., B. Kuylenstierna, L. Ernster, and A. Bergstrand. 1967. An electron-transport system associated with the outer membrane of liver mitochondria: a biochemical and morphological study. J. Cell Biol. 32:415-438.

Stieger, B., A. Marxer, and H.-P. Hauri. 1986. Isolation of brush-border membranes from rat and rabbit colonocytes: is alkaline phosphatase a marker enzyme? J. Membr. Biol. 91:19-31.

Stieger, B., K. Matter, B. Bauer, K. Bucher, M. Hoechli, and H.-P. Hauri. 1988. Dissection of the asynchronous transport of intestinal microvillar hydrolases to the cell surface. J. Cell Biol. 106:1853-1861.

Tabas, I., and S. Kornfeld. 1979. Purification of and characterization of a rat liver Golgi $\alpha$-mannosidase capable of processing asparagine-linked oligosaccharides. J. Biol. Chem. 254:11655-11663.

Tong, P. Y., W. Gregory, and S. Kornfeld. 1989. Ligand interactions of the cation-independent mannose 6-phosphate receptor. The stoichiometry of mannose 6-phosphate binding. J. Biol. Chem. 264:1962-1989.

Tooze, S. A., J. Tooze, and G. Warren. 1988. Site of addition of N-acetylgalactosamine to the El glycoprotein of a mouse hepatitis virus-A59. J. Cell Biol. 106:1475-1487.

Towbin, H., T. Staehelin, and J. Gordon. 1979. Electrophoretic transfer of proteins from polyacrylamide gels to nitrocellulose sheets: procedure and applications. Proc. Natl. Acad. Sci. USA. 70:4350-4354.

Tulsiani, D. R. P., and O. Touster, 1988. The purification and characterization of mannosidase IA from rat liver Golgi membranes. J. Biol. Chem. 263:5408-5417.

Vaux, D., J. Tooze, and S. Fuller. 1990. Identification by anti-idiotype antibodies of an intracellular membrane protein that recognizes a mammalian endoplasmic reticulum retention signal. Nature (Lond.). 345:495-502.

Venable, J. H., and R. Coggeshall. 1965. A simple lead citrate stain for use in electron microscopy. J. Cell Biol 25:407-408.

Warren, G. 1987. Signals and salvage sequences. Nature (Lond.). 327:17-18.

Wieland, F. T., M. L. Gleason, T. A. Serafini, and J. E. Rothman. 1987. The rate of bulk flow from the endoplasmic reticulum to the cell surface. Cell. 50:289-300.

Yewdell, J. W., and J. R. Bennink. 1989. Brefeldin A specifically inhibits presentation of protein antigens to cytotoxic T lymphocytes. Science (Wash. DC). 244:715-718. 